Edunomika - Vol. 05, No. 02 (2021)

\title{
PERANCANGAN MODEL PENINGKATAN KINERJA PADA PT. BANK ANZ INDONESIA
}

\author{
Tutik Winarsih \\ Program Studi Manajemen, STIE YAPAN Surabaya, Indonesia \\ E-mail: twinarsih@stieyapan.ac.id
}

\begin{abstract}
This research abstract aims to design the integrity model of PBSC and OBSC in determining the priority of corrective action at ANZ Bank Indonesia Sales Comercial Banking Division. This study uses qualitative approach with case study method. The type of research used in this study is a type of 'description research'. Design research design of PBSC and OBSC integration model to determine the priority of corrective action at ANZ Bank Indonesia Sales Commercial Banking Division. The results showed that in the external perspective of improvement of ANZ Indonesia Bank organizationally with the same perspective becomes a priority is to develop programs for goal-oriented marketing. In the perspective of knowledge and learning organizationally with the same perspective the priority is to conduct planning interviews, training and assessments with employees based on individual performance plans and capability profiles. In a financial perspective the priority is to close an unprofitable business unit.
\end{abstract}

Keywords: TPS, Organizational Balanced Scorecard, PBSC, Perspective Internal, External, Knowledge and Learning, Finance

\section{PENDAHULUAN}

Pesatnya perkembangan dunia menuntut organisasi untuk dapat bekerja cerdas, menyenangkan serta beretika sesuai dengan visi, misi, dan pengalaman tanpa bertolak belakang dengan keinginan pribadi, sehingga tujuan bersama dapat terwujud (Tunggal, 2001). Pengukuran kinerja merupakan sebuah alat pengendalian suatu organisasi, hal tersebut dapat mejadi alat ukur dalam kesuksesan organisasi. Selain itu pengukuran kinerja dapat membantu manajemen dalam penyediaan informasi terhadap perencanaan, pengendalian, ataupun perbaikan kinerja dimasa depan.

Persaingan organisisi yang kian ketat, peningkatan inflasi, perubahan teknologi yang kian canggih serta perubahan kondisi demografis yang dapat meninmbulkan perubahan kebutuhan konsumen. Menyikapi hal ini organisasi perlu megevaluasi atau mengkaji kembali strategi yang digunakan dengan data yang akurat serta valid. Secara garis besar, perencanaan stategi penting untuk mendapat keunggulan bersaing serta memiliki produk sesuai dengan keinginan konsumen, yang tentunya perlu dukungan optimal dari sumber daya yang ada terutama sektor perbankan.

ANZ sebagai salah satu organisasi perbankan terkemuka pada bidang sumber daya alam dengan kapabilitas yang kuat dalam pertambangan, agri bisnis dan perbankan komersial domestik dengan rangkaian produk yang lengkap, mencakup produk pinjaman, finance, manajemen mempunyai orientasi pada pelayanan kepada nasabah dan berfokus di wealth management, perbankan personal dan kartu kredit. Menurut kapitalisasi pasar per September 2015, Bank ANZ termasuk ke dalam 50 bank terbesar di dunia, memiliki lebih dari enam juta nasabah dan 35.000 karyawan yang tersebar di lebih 30 negara. ANZ merupakan salah satu dari 11 bank yang berpredikat AA+ di dunia dan baru-baru ini termasuk ke dalam peringkat bank teraman di dunia (Finance, 2015). 
Masih terbukanya pasar dengan tingkat kebutuhan yang tinggi, hal ini tentunya akan semakin memperketat persaingan antar bank di Indonesia.(Karsten \& Paramita, 2019) Globalisasi telah mengubah segala sesuatu yang membatasi menjadi lepas tak terbendung. Tiap-tiap perusahaan akan mudah mendaptkan sumberdaya yang diinginkan dimanapun dan kapanpun dengan perbaikan kinerja pribadi serta organisasi berkenanjutan dimana penerapan Total Performance Scorecard (TPS) dapat dijadikan sebagai senjata utama.

Total Performance Scorecard (TPS) lebih dari sekedar sistem pengukuran taktis atau operasional (Asriansyah, 2021). Total Performance Scorecard merupakan alat manajemen untuk memperjelas dan menerjemahkan visi dan strategi serta meningkatkan umpan balik dan pembelajaran strategis.(Sulistiani, 2017) Sehingga setiap anggota dalam organisasi dapat mengimplementasikan strategi sesuai dengan visi dan misi organisasi dan kinerja pribadi. Penggunaan Total Performance Scorecard (TPS)membantu organisasi dalam memfokuskan dan menyelaraskan tim eksekutif, unit bisnis, sumber daya manusia, teknologi informasi dan sumber keuangan mereka dengan strategi perusahaan. (Rampersad, 2005)

ANZ Indonesia sedang dalam perjalanan yang sangat berarti dalam membangun bank yang memimpin dengan kapabilitas perbankan dibidang korporasi (commercial banking) dimana dengan melayani segmen nasabah yang luas dan mengarah pada bankyang berorientasi pada hubungan dengan nasabah melalui pembangun value jangka panjang yang berkesinambungan bagi nasabah dan Bank. Indonesia adalah salah satu pasar kunci bagi ANZ Grup. Namun karena adanya pengaruh arus globalisasi dan perubahan lingkungan dunia usaha yang bergerak cepat yang pada gilirannya akan mendorong timbulnya persaingan yang semakin ketat, maka sudah saatnya dilakukan pembenahan dan penyesuaian dalam pengukuran kinerja agar tetap dapat bersaing dan dapat melangsungkan usahanya melalui penerapan Total Performance Scorecard (TPS) khususnya di commercial banking.

Berdasarkan pemaparan seperti yang tersebut diatas, sudah saatnya dipandang perlu untuk mengevaluasi manajemen strategi yang diterapkan Bank ANZ berbasis kinerja dimana dengan didasari oleh latar belakang penulisan di atas maka dapat dirumuskan permasalahan penelitian adalah "Bagaimanakah perancangan model integrasi PBSC dan OBSC untuk menentukan prioritas tindakan perbaikan pada Bank ANZ Indonesia Divisi Sales CommercialBanking ?".

Berdasarkan perumusan masalah yang dikemukakan diatas maka dapat ditentukan tujuan penelitiannya adalah menganalisis perancangan model integrasi PBSC dan OBSC untuk menentukan prioritas tindakan perbaikan pada Bank ANZ Indonesia Divisi Sales Commercial Banking.

\section{Tinjauan Pustaka}

\section{Total Performance Scorecard}

Rampersad (2003) dalam (Krupski et al., 2017) menyatakan Total Performance Scorecard (TPS) merupakan kumpulan penilaian kinerja secara terintegrasi dimana didefinisikan sebagai proses sistematis perbaikan, pengembangan, dan pembelajaran yang bersifat berkesinambungan, bertahap, dan rutin, yang terpusat kepada perbaikan kinerja pribadi dan organisasi secara berkelanjutan. Ketiganya terkait erat dan harus dijaga keseimbangannya, TPS mencakupa seluruh kesatuan misi dan visi organisasi, peran kunci, nilai inti, faktor penentu keberhasilan, tujuan, tolok ukur kinerja, target, serta tindakan perbaikan, dan juga proses hasil perbaikan, pengembangan, dan pembelajaran yang bersinambung dimana merupakan konsep gabungan dari Total Quality Management, Competence Management, Balanced Scorecard, Personal Balanced Scorecard.(Astuti \& Rifa'i, 2020) 


\section{Organizational Balanced Scorecard (OBSC)}

OBSC mencakup misi, visi, peran kunci, faktor penentu keberhasilan, sasaran, tolok ukur, kinerja, target, dan tindakan perbaikan organisasi (FARIZ \& WINARSIH, 2017). Selain itu ia juga menyebutkan bahwa sasaran organisasi adalah hasil yang harus dicapai dalam jangka pendek untuk mewujudkan ambisi bersama jangka panjang. Ukuran kinerja organisasi adalah indikator yang terkait dengan faktor penentu keberhasilan dan sasaran strategis, dan digunakan untuk menilai berfungsinya sebuah suatu proses. Ketika indikator tersebut dihubungkan satu sama lain sedemikian rupa sehingga manajer dapat menarik kesimpulan dari serangkaian tindakan, indikator tersebut sinyal tepat waktu kepada manajemen untuk memandu organisasi, berdasarkan pengukuran perubahan (proses) dan perbandingan hasilhasil yang diukur dengan standar yang ada. Sedangkan target organisasi adalah mengindikasikan nilai yang harus dicapai. (Ndevu \& Muller, 2018)

\section{Personal Balanced Scorecard (PBSC)}

PBSC mulai dikenalkan oleh Rampersad (2006), hal ini meliputi perbaikan bersinambung dari keterampilan dan perilaku pribadi, dengan fokus pada kesejahteraan dan keberhasilan pribadi dalam organisasi. Elemen PBSC dibagi dalam beberapa perspektif diantaranya: Internal (kesehatan fisik dan keadaan mental), Eksternal (hubungan dengan keluarga, atasan, rekan kerja dan yang lainnya), Pengetahuan dan pembelajaran (keterampilan dan kemampuan pembelajaran), Keuangan (stabilitas keuangan). Keempat prespektif dasar ini membentuk bagian integral misi,visi, dan peran kunci pribadi yang menghubungkan ambisi pribadi dan tindakan. (dalam (FARIZ \& WINARSIH, 2017))

\section{METODE PENELITIAN}

Penelitian ini menggunakan pendekatan kualitatif dengan metode studi kasus. Jenis penelitian ini adalah jenis 'description research'. Desain penelitian perancangan model integrasi PBSC dan OBSC untuk menentukan prioritas tindakan perbaikanpada Bank ANZ Indonesia Divisi Sales Commercial Banking merupakan studi kasus tunggal dimana untuk merancang Total Performance Scorecard tahapannya adalah:

1) Perumusan Personal Balanced Scorecard

2) Perumusan Organizational Balanced Scorecard.

3) Menyelaraskan Ambisi Pribadi dengan Ambisi Bersama.

\section{HASIL DAN PEMBAHASAN}

\subsection{Hasil penelitian}

Dari hasil wawancara dengan karyawan divisi sales Commercial Banking ANZ Indonesia yang tersebar dibeberapa kota besar seperti Jakarta, Bandung, Medan, Surabaya, Denpasar, Makassar, Manado, Balikpapan, Semarang dan Solo. Responden memiliki karakteristik usia antara 28-33 tahun,jenis kelamin laki-laki dan perempuan, status menikah maupun tidak menikah, dengan latar belakang pendidikan S1 dan S2. Memiliki pengalaman kerja di Commercial Banking minimal 3 tahun. Berdasarkan PBSC dan OSBC yang dirumuskan berdasarkan data lapangan, tidak ada hambatan yang berarti jika ANZ Indonesia ingin menerapkan TPS diorganisasinya dalam rangka meningkatkan kinerja dengan integritas. 


\subsection{Pembahasan}

\section{Perumusan Personal Balanced Scorecard}

Berdasarkan PBSC maka dapat diketahui rumusan tindakan perbaikan karyawan pada perspektif internal, antara lain: Menyisihkan waktu 20 menit setiap pagi untuk pengembangan diri; Menyeimbangkan waktu stres dengan waktu khusus untuk santai dan bersenang-senang; Menyelaraskan tindakan pribadi dengan ajaran agama; Terus melakukan kegiatan, tetapi menetapkan batas waktu secara ketat; Mementingkan kualitas tidur bukan kualitasnya.

Rumusan tindakan perbaikan karyawan pada perspektif eksternal, antara lain: Kegiatan membantu tanpa berupayamendapatkan keuntungan serta membangun sikap melayani terhadap orang lain; Mengembangkan pengetahuan dalam bidang manajemen khususnya keuangan dan pemasaran; Terbuka terhadap kebutuhan yang sesungguhnya; Melakukan lebih banyak hal-hal yang postifbagi orang lain; Berjuang untuk meningkatkan kepuasan nasabah; Melakukan FGD minimal satu minggu sekali mengenai pengembangan produk dan jasa baru; Memulai pertemuan informal setiap bulan; Weekly meeting untuk membahas masalah yang dihadapi dicabang; Mendengarkan dengan lebih baik terhadap rekan kerja dan karyawan, belajar untuk tidak arogan dan menghargai mereka.

Rumusan tindakan perbaikan karyawan pada perspektif pengetahuan dan pembelajaran, antara lain: Lebih proaktif, lebih efektif, lebih berfokus pada hasil dan bertindak lebih persuasif; Menerapkan brainstorming dan mind mapping lebih sering dan lebih sistematis; Berani melakukan sesuatu yang baru untuk kembangkan kepercayaan diri; Mengikuti pelatihan penyelesaiankonflik danetika perusahaan; Mampu memanajemeni kelompok secara meyakinkan tanpa merasa takut; Bertukar pengalaman dan berbagi pengetahuan dengan orang lain. Serta rumusan tindakan perbaikan karyawan pada perspektif keuangan, antara lain : Mencari strategi investasi yang terbukti berhasil; Belajar menggunakan keterampilan secara lebih baik; Mengatur asuransi pensiun.

\section{Perumusan Organizational Balanced Scorecard}

OBSC dapat dirumuskan tindakan perbaikan, pada perspektif internal antara lain: Banyak menjalin komunikasi dengan perusahaan keuangan; Terus memperbesar jangkauan pelayanan; Memberikan training untuk pelatihan tim efektif; Melakukan studi perbaikan kondisi kerja; Melakukan studi kepuasan karyawan; Mengembangkan formula untuk perluasan jasa yang diberikan kepada nasabah; Mengatur pengembangan organisasi secara lebih efisien; Menentukan kriteria pengembangan untuk produk dan jasa baru.

Rumusan tindakan perbaikan, pada perspektif eksternal antara lain: Memperluas kegiatan di seluruh kota besar di Indonesia; Mengembangkan program untuk pemasaran berorientasi tujuan; Komunikasi dengan nasabah melalui sarana e-bisnis; Membuat database yang mencakup karakteristik nasabah berpotensi; Membuat pedoman untuk kepuasan optimal nasabah; Memberikan penghargaan tambahan kepada karyawan yang berorientasi nasabah; Merumuskan prosedur keluhan nasabah dan melaksanakannya; Mengembangkan dan menerapkan rencana untuk memperbaiki kepercayaan dan kesetiaan nasabah; Mengadakan studi Citra.

Rumusan tindakan perbaikan, pada perspektif pengetahuan dan pembelajaran, antara lain: Membuat rencana pengembangan karier untuk seluruh karyawan; Melakukan wawancara perencanaan, pelatihan dan penilaian dengan karyawan berdasarkan rencana kinerja perorangan dan profil kemampuan; Menghubungkan imbalan kinerja dengan sistem penilaian; Menyediakan pelatihan dalam kepemimpinan efektif; Memperkenalkan sistem informasi manajemem; 
Mengukur tingkat kepuasan nasabah; Memberikan pelatihan bekerja dalam tim; Menawarkan penghargaan untuk "saran perbaikan terbaik"

Sedangkan rumusan tindakan perbaikan, pada perspektif keuangan antara lain: Menaikkan biaya administrasi sebesar 5\% untuk level menengah ke atas; Meluaskan paket pelayanan kepada nasabah; Menutup unit bisnis yang tidak menguntungkan; Mengkaji ulang ulang proses dan melaksanakannya dengan lebih efisien.

\section{Menyelaraskan Ambisi Pribadi dengan Ambisi Bersama}

Berdasarkan pada hasil penelitian dapat dilihat perbaikan pribadi karyawan Bank ANZ Indonesia divisi Sales Commercial Banking pada perspektif internal yang menjadi prioritas adalah terus melakukan kegiatan, tetapi menetapkan batas waktu secara ketatdimana diharapkan terus menerus meningkatkan kekuatan batin dan terus menjaga keseimbangannya dengan kesehatan fisik, sedangkan pada perbaikan Bank ANZ Indonesia secara organisasi dengan perspektif yang sama yang menjadi prioritas adalah mengatur pengembangan organisasi secara lebih efisien. Tentunya, hal ini dapat dikatakan bahwa pada perspektif internal terdapat keselarasan.

Pada perspektif ekternal yang menjadi prioritasi adalah mengembangkan pengetahuan dalam bidang manajemen khususnya keuangan dan pemasaran dimana diharapkan mendukung keberhasilan organisasi, sedangkan pada perbaikan Bank ANZ Indonesia secara organisasi dengan perspektif yang sama menjadi prioritasa dalah mengembangkan program untuk pemasaran berorientasi tujuan. Sehingga dapat dikatakan bahwa pada perspektif internal terdapat keselarasan. Pada perspektif pengetahuan dan pembelajaran dapat dlihat tindakan perbaikan pribadi karyawan Bank ANZ Indonesia Banking yang menjadi prioritas ialah lebih proaktif, lebih efektif, lebih berfokus pada hasil dan bertindak lebih persuasif.

Sedangkan perbaikan Bank ANZ Indonesia secara organisasi dengan perspektif yang sama menjadi prioritas adalah melakukan wawancara perencanaan, pelatihan dan penilaian dengan karyawan berdasarkan rencana kinerja perorangan dan profil kemampuan. Dengan kata lain pada perspektif pengetahuan dan pembelajaran terdapat keselarasan dalam hal pelaksanaan.

Pada perspektif keuangan dapat dilihat tindakan perbaikan pribadi karyawan Bank ANZ Indonesia divisi Sales Commercial Banking yang menjadi prioritas adalah mencari strategi investasi yang terbukti berhasil, sedangkan pada perbaikan Bank ANZ Indonesia secara organisasi dengan perspektif yang sama menjadiprioritas adalah menutup unitbisnis yangtidak menguntungkan. Berdasarkan hal tersebut dapat dikatakan bahwa pada perspektif keuangan terdapat keselarasan dalam hal pelaksanaan serta tujuan yang hendak dicapai dimana hasil akhirnya adalah keselarasan ini menciptakan kinerja yang baik bagi ANZ Indonesia untuk bersaing merebut hati para pelaku bisnis di Indonesia khususnya bagi divisi Commercial Banking dan meningkatkan citra ANZ Indonesia sebagai bank yang terpercaya sehingga masyarakat semakin tertarik memanfaatkan produk-produknya.

\section{KESIMPULAN}

Perbaikan pribadi karyawan Bank ANZ Indonesia divisi Sales Commercial Banking pada perspektif ekternal perbaikan Bank ANZ Indonesia secara organisasi dengan perspektif yang sama menjadi prioritas adalah mengembangkan program untuk pemasaran berorientasi tujuan. Pada perspektif pengetahuan dan pembelajaran secara organisasi dengan perspektif yang sama menjadi prioritas adalah melakukan wawancara perencanaan, pelatihan dan penilaian dengan karyawan berdasarkan rencana kinerja perorangan dan profil kemampuan. Pada perspektif 
keuangan perbaikan Bank ANZ Indonesia secara organisasi dengan perspektif yang sama menjadi prioritas adalah menutup unit bisnis yang tidak menguntungkan.

\section{DAFTAR PUSTAKA}

Asriansyah, R. (2021). Pengukuran Tingkat Kinerja Perusahaan Dan Usulan Perbaikan Menggunakan Metode Total Performance Scorecard (TPS)(Studi Kasus di CV Mega Jaya Logam, Bakalan Baru, Ceper, Klaten, Jawa Tengah). UPN" Veteran" Yogyakarta.

Astuti, T. B., \& Rifa'i, M. (2020). Application Of Total Quality Management (Tqm), Performance Measurement System And Effectiveness Systems On Managerial Performance: Application Of Total Quality Management (Tqm), Performance Measurement System And Effectiveness Systems On Managerial Performance. Jurnal Mantik, 4(1), 739 743.

FAriz, F., \& Winarsih, T. (2017). Perancangan Model Integrasi PBSC Dan OBSC Untuk Menentukan Prioritas Tindakan Perbaikan Pada Bank Anz Indonesia Divisi Sales Commercial Banking. MAPAN: Jurnal Manajemen Akuntansi Palapa Nusantara, 1(1), 9.

Finance, G. (2015). Global Finance names the world's 50 safest banks 2015. URL: Https://Www. Gfmag. Com/Media/Press-Releases/Global-Finance-Namesworlds-50-Safest-Banks-2015 (Дата Звернення: 10.10. 2016).

Karsten, J., \& Paramita, S. (2019). Strategi Media Relations Praxis dalam Membangun Corporate Image Bank DBS Indonesia. Prologia, 3(2), 473-480.

Krupski, R., Piórkowska, K., \& Sus, A. (2017). Organizational endogenous development: The micro-foundations, opportunities and real options perspective. Argumenta Oeconomica, 1 (38).

Ndevu, Z. J., \& Muller, K. (2018). Operationalising performance management in local government: The use of the balanced scorecard. SA Journal of Human Resource Management, 16(1), 1-11.

Rampersad, H. K. (2005). Total Performance Scorecard: Aligning Human Capital with Business Strategy and Ethics. Nanyang Business Review, 4(1), 72-99.

Sulistiani, D. (2017). Penerapan Total Performance Scorecard (TPS) Dalam Upaya Membangun Komitmen Pegawai Di Organisasi Sektor Publik. J-Mpi (Jurnal Manajemen Pendidikan Islam), 2(1), 38-49.

Tunggal, A. W. (2001). Pengukuran kinerja dengan balanced scorecard. Harvindo. Jakarta. 